\title{
Factors Influences the Effectiveness of Internal Audit Services at Ministry of Finance and Planning in Zanzibar
}

\author{
Zuwena Amour Suleiman ${ }^{1} \quad$ Abdalla Ussi Hamad ${ }^{2} \quad$ Salama Yussuf ${ }^{3}$ \\ 1. MSc. (Economic and Finance) Students, Zanzibar University \\ 2.Lecturer, Faculty of Arts and Social Science, Zanzibar University \\ 3.Senior lecturer, Faculty of Business Administration, Zanzibar University
}

\begin{abstract}
The main purpose of the study was to examine the factors influencing effectiveness of internal audit services at the Ministry of finance Zanzibar. The methodology of the study based on descriptive and inferential research approach which is quantitative in nature and purposive sampling procedure used to select the respondents. Findings of the study indicated that professional qualifications of auditors, internal audit independence, sufficient of audit resources (Quality) and management support to internal auditing have influencing the effectiveness of internal audit services at the Ministry of finance Zanzibar. Based on the results it is recommended that management in Public sector organization should provide necessary facilities to internal audit department in order to create a committed work force for better organization performance.
\end{abstract}

Keywords: Internal Audit, Principal Components Analysis, MoF

DOI: $10.7176 / \mathrm{RJFA} / 12-2-02$

Publication date: January $31^{\text {st }} 2021$

\section{Introduction}

There have been increasing calls for the public sectors to establish strong internal control in many developing nations including Tanzania to provide quality public services that meet the needs of its citizens, be more accountable for its decisions and actions and to manage resources more prudently (Likierman, 2003). These calls have been made on account of the essential role the sector plays and the contribution it brings to the development process, especially in developing countries (Hemming and Mansoor 1988).

In Zanzibar there is internal audit unit in the ministries, according to Public Finance Regulation Act (2005) in section 28 and 30 give the Accounting officer authority to establish internal audit unit and audit committee respectively throughout the ministry, department or Agency. The internal Auditor General is a head of internal audit services that coordinate, facilitate, monitor and supervise internal audit activities within ministries, departments, institutions, Agencies and local government in order to secure quality assurance of internal audit functions of the government. Internal Audit General in performing the functions of internal audit services shall carry out specific investigations.

In order to perform well their functions, $\mathrm{CAG}$ has the following power; to obtain information and explanations concerning all accounts of government and inspect books, records in performing of duties. Furthermore, the responsibilities of CAG to internal audit services are; developing internal audit polices rules, standards, manuals, circular and guidelines. Review and appraising compliance to laid down laws, regulations, standards, systems and procedures in Public Institutions including donor funded projects and to ensure control and proper accountabilities of public moneys and properties.

Specifically, the Ministry of Finance (MoFP) - Zanzibar, has a problem of ineffective internal controls which cause the problem of misuse of public resources, clearly evidence shown by CAG said that, ".... in the development programmed "MACEMP" the fund allocated are not properly utilized" (CAG, 2011/12). So the establishment of strong internal audit unit to enhance the efficient use of public resources is vital to any public sector organization or ministry so that to ensure proper management of those public resources (Bond and Dent, 1998; Barret, 2004; Caridad, 2005). This study was focused on assessing the factors that contributes to the effectiveness of internal audit services taking Ministry of Finance and Planning as a case.

\section{Problem of the Paper}

It is believed that most of the public enterprises in Zanzibar have poor application of internal audit principles and procedures which leads to blatant diversion of scarce resources with its attendant consequences on the traditional accountability of government to the public. Notwithstanding, these sectors failed to deliver on the purposes for which they were established and many people accuse managers of public enterprises in Zanzibar for ineffectiveness and inefficiency in terms of resource control.

To such issues explained above, most of public sectors (including Ministry of Finance in Zanzibar) established internal audit departments with well qualified staff, charged with responsibility of providing management with re-assurance that public resources are efficiently and effectively utilized. However, internal audit services in public sectors organization is still ineffective due to the problem of misuses of public resources 
and poor financial performance, where budgets are not followed, rules and regulations on the use of resources are not adhered to and there is massive unaccounted of funds in Zanzibar (Auditor General, 2008).

Strategically, Internal Audit is an important unit that must act ethically for national development and for the benefit of general public. It is responsible for providing efficient audit services to enhance accountability and value for money in the collection and use of public resources. Objectively, Internal Audit is supposed to be impartial unit offering services to the organization with professional integrity and high ethical standards based on acknowledged best practices.

Therefore, this study examine the factors that contribute to the effectiveness of Internal Audit services and bring value to the laid down framework governing the auditing services in Ministries and other public sector organizations, so as to remove the list of shortfalls in a number of Institutions and various major deals conducted in the country.

\section{Literature review}

\subsection{Theoretical literature review}

A theoretical framework consists of concepts, together with their definitions, and existing theory/theories that are used for a particular study (Khan, 2010). In this study, two theories have been used to clarify the main objective of this study.

3.1.1 The Policeman Theory

This was the most widely held theory on auditing until the 1940s (Hayes et al., 1999). The theory claims that the auditor is responsible for searching, discovering and preventing fraud. In the early 20th century this was certainly the case. However, more recently the main focus of auditors has been to provide reasonable assurance and verify the truth and fairness of the financial statements. The detection of fraud is, however, still a hot topic in the debate on the auditor's responsibilities, and typically after events where financial statement frauds have been revealed, the pressure increases on increasing the responsibilities of auditors in detecting fraud (Hayes, 2005).

3.1.2 Agency Theory

Agency relationship could be defined as a contract among the organization owner(s) and its top management. Managers work with the organization as agents to perform some service on behalf of owners who delegate some decision making authorities to managers. These authorities could be misused by managers to meet their own personal interests. Therefore, the existence of the audit committees and the external and internal auditors will help the organization in enhancing their performance, and also will ensure that the management carries out its plans according to procedures (Adams, 1994). Peursem and Pumphrey (2005) considered internal auditors as agents and monitors for a variety of the internal audit users that include the board, audit committee and senior management. Agency problems could occur when the board or its audit committee is inefficient, and hence, the senior management is likely to be a powerful influence over the internal audit. This complex web creates an inherent dilemma for the internal audit: how can it carry out their monitoring role over management if it is ineffective itself? Internal auditors often are employed by senior management, but at the same time, they are also agents of the board and audit committee who trust in the internal auditors ${ }^{\text {ee }}$ ability to evaluate senior management's works.

\subsection{Empirical literature}

Zulkifli (2014) investigates the factors that contribute to the effectiveness of internal audit in the Malaysian public sector. The study intended to determine the auditors ee perception toward the effectiveness of internal audit work, influenced by the quality of audit work in order to perform in an effective manner as control instrument in public financial management. It also aimed to determine the relationship between factors that contribute to the effectiveness of Internal Audit works in promoting better transparency and integrity of public management. The scope of this study covered the internal auditors that work in the ministries in Putrajaya.

Furthermore, Nankunda (2013) examined the internal audit function and financial performance of public sector organizations and use cross-sectional research design, the study concluded that, there are number of internal control systems at National Water and Sewerage Corporation public sector organization. including; checking of goods entering National Water and Sewerage Corporation after their purchase, checking of people at the building entrance, frequency supervision of the Municipal activities, writing of reports to the National Water and Sewerage Corporation workers concerning all that has been done under departments by the heads of departments every after two months, use of recording systems, internal audit system, training and workshop programs to the corporation employees, screening of prospective employees in addition to the use of budgetary and financial controls, also it indicated a positive impact of internal audit function on the financial performance of the corporation.

According to (Shiella, 2012) he found out that, Internal audit is not in a position to influence the proper management of public resources, because public sector managers do not support internal audit due to the fact that, public sector managers are not aware of the exact role of the internal auditors due to the evolution of the internal audit activities and also, public sector managers do not see the relevance of the internal audit activities in the public sector organizations. However he argued that, the presence of employ qualified professionals, motivated and are 
well resourced, the internal auditors will help managers to reach their objectives and will get the support from those managers. On the other hand the research conducted by the (Pavlatos \& Paggios, 2009) showed that internal audit unit is highly effective in increasing the reliability of accounting data, existence of physical assets and in protecting against fraudulent activities so as to ensure efficient use of public resources in public sectors.

In the analysis of (Badara, 2012) who did a research on "The Role of Internal Auditors in Ensuring Effective Financial Control at Local Government Level" It concluded that, internal auditors should exercise the degree of independency on various department within the organization in performing their duties, also pointed out that the internal auditing system should be efficient in such a way that it will prevent any act of financial crime, misuse of public resources and detection of fraud. In addition he concluded that, central government should established a scheme for internal auditors training from time to time because it will enhances their operational capacities and skills in administering the internal control system by way of attending professional seminars, workshop and symposium.

Furthermore, Cohen and Sayag (2010) studied 'effectiveness of internal auditing: An Empirical Examination of its Determinants in Israeli organization'. With the use of questionnaire and mail survey of 292 organizations, the study identified management support, especially in relation to provision of proficient internal audit staff, career development and independence of internal auditors as vital to the effectiveness of internal audit. In another study conducted by Theofanis, Drogalas and Giovanis (2011) on the 'relationship between elements of internal control system and internal audit effectiveness' with the use of 52 Hotels in Greek through mail survey, the results reveal positive relationship between the variables. However, they suggested that with larger samples the outcome of the study might differ significantly from their own. In other words, internal audit unit can effectively check fraud and fraudulent activities in the Public Sector if they are independently, adequately resourced, qualified professionals and have significant numbers of staff, obviously Internal Audit Departments will function effectively (Okechukwu, 2011).

In a study carried out by Ahmad, Othman \& Jusoff (2009) on effectiveness of internal audit in Malaysian public sector in which simple percentage was used as the tool for data analysis; they found that lack of audit staff was a major impediment to effective internal auditing. One of the major limitations of the study was a narrow scope. Arena and Azzone (2009) in their study entitled 'identifying organizational drivers of internal audit effectiveness in Italy' with the use of 153 Italian companies and survey method, found that characteristics of the internal audit team, the audit processes and activities as well as organizational links influenced effectiveness of internal audit.

\section{Methodology}

Under the philosophical assumption, the positivism was adopted for this study for several reasons. The main reason of being that, it fits the quantitative research design used in this study. Also, there is need to use method and philosophy that fit together the in-sights provided by quantitative research into a workable solution. Therefore, the quantitative research design is employed in this study since it allows the researcher to explore, explain a phenomenon, and interpret data statistically in a wider and easy ways.

For data collection and analysis, the questionnaire is developed based on a Likert scale because it includes question which require the respondents to indicate how much or to what extent they agree or disagree with the given statement on each construct. Following this type of rating scale, the options range is from lowest to highest responses that are 1 to 5 respectively. These options are; strongly disagree $(\mathrm{SD})=1$, disagree $(\mathrm{D})=2$, neutral $(\mathrm{N})$ $=3$, agree $(\mathrm{A})=4$, strongly agree $(\mathrm{SA})=5$

Stratified random sampling is used to distribute 50 questionnaires to the respondent (account section, audit section human resources sections and other ministry staff) are distributed and all are collected. Respondents are classified by gender, age, level of education, work experience and field of work. Cronbach's Alpha test was conducted to measure the reliability of the instrument for all items and the result is .699 indicating a satisfactory level of internal consistency. A descriptive statistical tool of analysis and inferential statistics were used for analysing the data.

\section{Result and discussion}

\subsection{Demographic Features of the Respondents}

In this study, characteristics of respondents were examined in order to identify which demographic feature is more sensitive to the given the problem of investigation at stake. Therefore, characteristics namely, age, gender, education, working experience and field of work of the 50 respondents were examined as clearly observed in Table 1:- 
Table 1 Demographic Feature of the Respondents

\begin{tabular}{|l|l|l|}
\hline Variable & Category & Percentage (\%) \\
\hline Gender & Male & 40 \\
& Female & 60 \\
\hline \multirow{5}{*}{ Age } & $20-30$ & 34 \\
& $31-40$ & 40 \\
& $41-50$ & 10 \\
& $51-$ above & 16 \\
\hline Education & Master degree & 40 \\
& First degree & 36 \\
& Diploma & 18 \\
& Certificate & 6 \\
\hline Work experience & $1-5$ years & 40 \\
& $6-10$ years & 30 \\
& $11-20$ years & 26 \\
& 20 years and above & 4 \\
\hline Field of work & Accounting \& Finance & 50 \\
& Business management & 12 \\
& Economics & 20 \\
& Others & 18 \\
\hline
\end{tabular}

From the table 1 above summarises the demographic information about the respondents. Expectedly, the number of male respondents is a bit higher compared with the number of female. The researcher was intended avoid gender sample bias in the data. The age of the respondents in the social research is the one of the most important characteristics in capturing their views about a particular problem (Abideen 2010). The result in the table above it seems to suggest 50 percent of the respondents are between the ages of 31-50, which is half of the total respondents. This indicates that most of the workers in the ministry of finance in Zanzibar are economically active labor force and they can manage well their work responsibilities and taking the responsibilities to their family.

An overwhelming number of the respondents (76 percent) are educated from first degree up to master degree level and the remaining 24 percent of the respondents are educated from certificate to diploma level. More considerably, very few number staff representing 4 percent have experience in their position 20 years and above while 70 percent of the total respondents have 1 to 10 years of work experience.

More importantly, 50 percent of total respondents for this study were from accounting and finance as the main target to get the information about internal audit services in the ministry of finance in Zanzibar. And the remaining 50 percent were from business management, economics and other department. The implication of this result is that, 50 percent of the total respondents were from related field of this study, it is most probably provide the information in reality.

\subsection{Descriptive statistics analysis}

The study was examining the factors that influence the effectiveness of internal audit services at Ministry of Finance and Planning in Zanzibar. The analysis was done first through descriptive and the following results were obtained. Four factors were identified and examined on their effectiveness on internal audit. The following responses were obtained from respective respondents.

Table 2. Factors that influence the effectiveness of internal audit

\begin{tabular}{|l|l|l|l|l|l|l|l|l|l|l|}
\hline Statement/Level of Agreement & SA & $\mathbf{\%}$ & $\mathbf{A}$ & $\mathbf{\%}$ & $\mathbf{N}$ & $\mathbf{\%}$ & $\mathbf{D}$ & $\mathbf{\%}$ & SD & $\mathbf{\%}$ \\
\hline $\begin{array}{l}\text { Professional qualifications of auditors (The } \\
\text { Competence) }\end{array}$ & 36 & 72 & 10 & 20 & 0 & 0 & 0 & 0 & 4 & 8 \\
\hline Internal audit independence & 32 & 64 & 10 & 20 & 2 & 4 & 0 & 0 & 6 & 12 \\
\hline Sufficient of audit resources (Quality) & 4 & 8 & 1 & 2 & 15 & 30 & 0 & 0 & 30 & 60 \\
\hline Management support to internal auditing & 43 & 86 & 7 & 26 & 0 & 0 & 0 & 0 & 0 & 0 \\
\hline
\end{tabular}

The findings from the table above shows that 72 percent were strongly agreed with qualification of internal auditors at MoFP while only 8 percent of the respondents strongly disagreed with professional qualification of internal auditors at MoFP. The results in this part imply that, internal auditors of MoFP have enough professional qualification to perform their duties effectively. These findings are consistent with the study of Shir Chen, Cheng Yang and Fang Yang (2020). Although, the researcher wanted to know the efficient of internal auditors by asked the question related with internal audit independent at MoFP and found that about 64 percent of the respondents said "strongly agreed" it means internal audit unit at MoFP is independent enough to perform their duties and 12 percent strongly disagree with independent of internal auditors at MoFP. The implication of the finding is that, 
internal auditors at MoFP perform well their duties with regard to checking of financial records monthly and they are independent because the data obtained meets the minimum decision criteria provided by researcher which is above $(50 \%)$.

Another area of interest relates to whether or not the internal audit of Ministry of Finance and Planning has sufficient resources to perform their functions accordingly. The findings revealed that 60 percent of the respondents strong disagreed with the question and argued that Ministry of Finance and Planning has insufficient resources to perform their duties. Another group of population of 30 percent of respondents said that they have no sure on whether internal audit at MoFP have sufficient resources or not.

Finally, the researcher requested the respondents to outline their views relating to the management support towards internal audit services at MoFP. The study revealed that 86 percent of the respondents stated that, management of MoFP provide enough support to internal audit department. Though the percentage of management to providing support is higher it shows how the life of internal audit unit at MoFP is improved through the provision of such services.

\subsection{Principal components analysis}

Also, in this paper the researchers used a principal component analysis/factor analysis to generalize the problem drawn from the interrelationships (correlations) of large number of variables by defining a set of common underlying dimensions, known as factors. The main objective of performing factor analysis in this study is to reduce the data by summarizing the important information contained in the objective two by a fewer number of factors. Again, factor analysis was performed to determine the important measurable variable that explains the issue. The factor analysis was used to identify the most factor influences the effectiveness of internal auditing service services at MoFP. The result identify that most factor out of 5 resulted in extraction of several components. The outputs of factor analysis are;

5.3.1 Descriptive statistics for the principal factor analysis

For the descriptive statistics, reasonable results are achieved. This is because each item is measured on a 5 point Likert scale and there are no value that exceed five or below. The standard deviations are all nearly similar and show how far each item's score is from the mean. The number of valid cases seem adequate; according to Duran and Stival (2015), sample size of 50 and above is considered as acceptable. This study uses the sample size of 50. Therefore, the results derived from this data are safe

Table 4.14 Descriptive Statistics

\begin{tabular}{|l|r|r|r|r|}
\hline & Mean & Std. Deviation & Analysis N & Missing N \\
\hline Management support to internal auditing & 1.84 & 1.267 & 50 & 0 \\
Independence Factor & 2.04 & 1.195 & 50 & 0 \\
Qualifications factor & 1.88 & 1.100 & 50 & 0 \\
Sufficiency Factor & 3.26 & 1.139 & 50 & 0 \\
Other Factor & 1.61 & .451 & 50 & 0 \\
\hline
\end{tabular}

Source: Data Extraction, 2020

5.3.2 Total Variance Explained

Here decision was made as to which factor extraction methods are to be used. Based on the result 2 factors were found to have Common Factor that is were found appropriate and are most factors influences the effectiveness of internal auditing service services at MoFP based on the collected information.

Table 4.15 Total Variance Explained

\begin{tabular}{|c|c|c|c|c|c|c|c|c|c|}
\hline \multirow[b]{2}{*}{ Component } & \multicolumn{3}{|c|}{ Initial Eigenvalues } & \multicolumn{3}{|c|}{$\begin{array}{c}\text { Extraction Sums of Squared } \\
\text { Loadings } \\
\end{array}$} & \multicolumn{3}{|c|}{$\begin{array}{c}\text { Rotation Sums of Squared } \\
\text { Loadings } \\
\end{array}$} \\
\hline & Total & $\begin{array}{c}\% \text { of } \\
\text { Variance }\end{array}$ & $\begin{array}{c}\text { Cumulative } \\
\%\end{array}$ & Total & $\begin{array}{c}\% \text { of } \\
\text { Variance }\end{array}$ & $\begin{array}{c}\text { Cumulative } \\
\%\end{array}$ & Total & $\begin{array}{c}\% \text { of } \\
\text { Variance }\end{array}$ & $\begin{array}{c}\text { Cumulative } \\
\%\end{array}$ \\
\hline 1 & 1.803 & 36.070 & 36.070 & 1.803 & 36.070 & 36.070 & $\begin{array}{r}1.64 \\
3\end{array}$ & 32.869 & 32.869 \\
\hline 2 & 1.345 & 26.902 & 62.972 & 1.345 & 26.902 & 62.972 & $\begin{array}{r}1.50 \\
5\end{array}$ & 30.103 & 62.972 \\
\hline 3 & .724 & 14.483 & 77.455 & & & & & & \\
\hline 4 & .646 & 12.918 & 90.373 & & & & & & \\
\hline 5 & .481 & 9.627 & 100.000 & & & & & & \\
\hline
\end{tabular}

Extraction Method: Principal Component Analysis.

The interpretation from the table above was used and only the factors having eigenvalues greater than 1 were considered significant and selected. All factors with eigenvalues less than 1 were considered best summarize the total components. The results of analysis are shown on Table 4.15. The analysis identified 2 dominant factors that explain about $62.972 \%$ cumulative percentage of the total variance. Which explain the most factors namely, 
Management support to internal auditing and Independence factor.

\section{Conclusion and Recommendation}

The study objective was to the factors influences the effectiveness of internal audit services at Ministry of Finance and Planning in Zanzibar. This objective is achieved where all factors seem to have impacts to the organization. The findings showed that all respondents which form almost 90 percent agree that professional qualifications of auditors, internal audit independence, sufficient of audit resources (Quality) and management support to internal auditing have an impact to the Ministry of Finance and Planning. This implied that, existence of internal audit department is valuable in the development of any organization.

The study recommend that the internal auditors should be trained to use Integrated Financial management systems (IFMS) as other departments such as accounting department so as to have ability to conduct auditing in all area of government transactions. Also the Ministry should come up with strong policies to manage allocation of resources and to make sure that there are effective internal controls for better performance. Lastly, the management and the whole unit of internal audit should be given freedom on performing its task, this is very crucial for the effectiveness of the unit, on top of that in supporting the internal audit unit the higher authority at the ministry should provide all necessary facilities so as to help them accomplish their duties efficiently and effectively.

\section{References}

Adewale, A. A. (2010). Glocalization of Microfinance as a Strategy to Alleviate Intergenerational Transmission of Poverty in Nigeria. International Islamic University Malaysia.

ACCA (2005) Auditing and Assurance Services. Paper 3.1 Text book: Foulks Lynch Publication.

Arora, M.L. (2000) Book - keeping, Principles of Accounting and Auditing. Tanzania: NBAA.

Audit Reports for the Tanzania Ministry of Health and Social Welfare Fiscal years 1999-2010 Africa Confidential Journals, (March, 2012): Vol 53, No 6.

Ahmad, H. N., Othman, R., Othman, R. \& Jusoff, K. (2009), "The Effectiveness of Internal Audit in Malaysian Public Sector", Journal of Modern Accounting and Auditing, 5(9), 53-62

Arens, A. A., R. J. Elder, dan Besley M. S. 2008. Auditing and Assurance Services.12th edition. Prentice Hall. Boynton W.C, J. Wiley and Sons (1986) Modern Attwood.F.A Auditing (7th Ed). London. Pitman Publishing L.t.d.

Holmes and Burns. (1939). Auditing Standards and Procedures (9th Ed). U.S.A: American Institute of Certified Public Accountant.

Kothari, R. (2004). Research Methodology, Methods and Techniques. New Delhi: New Age International (P) Ltd. Magnus Ohman (July 2011) FES Senior Political Finance Advisor: Abuse of state resources.

Fernald, LD (2004). Methodology of Education Research. (3rd Ed.): New Delhi: Vikas Publishing House Pvt. Ltd. 8)

Millchamp A.H (1986) Auditing. (4th ed). London: published by D.P Publications ltd.

Millichamp, A.H. (1992) Auditing: An Instructional Manual for Accounting Students: London. Elbs - Df. Publication LTD,

National forum of Educational Administration \& Supervision Journal volume 27, number 4, 2010 (A safeguard against misuse of public funds) by Fred C. Lunenburg.

NBAA (2002) Tanzania Auditing Standards (TAS). (2nd Ed): Published by NBAA.

Nagy, A.L., Cenker, W.J. (2002), "An assessment of the newly defined internal audit function", Managerial Auditing Journal, Vol. 17 No.3, pp.130-7.

IIA (1999b), (The) Institute of Internal Auditors, available at (accessed 24 June 2006) Parliamentary Report on Richmond Scandal (May 1, 2008) by Dr Mwakyembe.

Spraakman, G. (1997), "Transaction cost economics: a theory of internal audit", Managerial Auditing Journal, Vol. 17 No.7, pp.323-30.

Stern, G.M. (1994), "15 ways internal auditing departments are adding value", Internal Auditor, Vol. 51 No.2, pp.30-3.

Sawyers L.B (1973) Internal Auditing. (4th Ed). Altamonte Springs Florida. U.S. A

Spencer K.H Pickett (2003) The Internal Auditing. (2nd edition) .London: British Library Publisher

Tanzania Country Report, (August, 2011). Art. No Sida 6145en by: Charlotte Vailant, Imran Ahmed, Deborah Manifield and Issac Kiwango

Working paper presented at the International Society for Third-Sector Research (ISTR) Fourth International Conference, Dublin, Ireland, July 7, 2000

Zanzibar Public Finance Regulation Act (2005)

Zanzibar Controlor and Auditors General Report for the year 2011/2012 